\title{
PEMANFAATAN PORTAL RUMAH BELAJAR UNTUK MENINGKATKAN KUALITAS PEMBELAJARAN
}

\author{
Utilization of Portal Rumah Belajar to Increase \\ Learning Quality
}

\author{
Bambang Warsita \\ Pusat Teknologi Informasi dan Komunikasi Pendidikan dan Kebudayaan, Kemendikbud \\ JI. RE. Martadinata, Tromol Pos 7/CPA Ciputat 15411, Tangerang Selatan, Banten, Indonesia \\ bambang.warsita@kemdikbud.go.id atau bwarsita08@gmail.com
}

\begin{abstract}
ABSTRAK: Pemanfaatan Teknologi Informasi dan Komunikasi (TIK) telah melahirkan model pembelajaran baru yaitu pembelajaran online atau pembelajaran berbasis web. Salah satu web pembelajaran adalah Portal Rumah Belajar, dengan alamat url: http://belajar.kemdikbud.go.id. Permasalahan yang ada kemudian adalah bagaimana pemanfaatan Portal Rumah Belajar sebagai sumber belajar, sarana pembelajaran kelas maya, dan sarana untuk peningkatan kualitas pembelajaran. Penulisan artikel ini bertujuan untuk mendeskripsikan pemanfaatan Portal Rumah Belajar sebagai sumber belajar, sarana pembelajaran kelas maya, dan sarana untuk peningkatan kualitas pembelajaran. Metode yang digunakan adalah studi literatur dari berbagai hasil kajian maupun hasil penelitian yang relevan dengan pemanfaatan Portal Rumah Belajar. Hasil kajian menunjukkan bahwa Portal Rumah Belajar dapat dimanfaatkan sebagai: (1) sumber belajar untuk memperoleh konten atau bahan belajar; (2) sarana pembelajaran kelas maya, yaitu untuk memfasilitasi terjadinya pembelajaran online antara peserta didik dan guru kapan saja dan di mana saja; dan (3) sarana untuk meningkatkan prestasi hasil belajar peserta didik yang pada gilirannya dapat meningkatkan kualitas pembelajaran. Simpulannya, pemanfaatan Portal Rumah belajar terbukti efektif untuk meningkatkan kualitas pembelajaran. Oleh karena itu, disarankan agar para peserta didik, guru, dan masyarakat luas, atau siapa pun yang mau belajar, dapat memanfaatkan Portal Rumah Belajar.
\end{abstract}

Kata Kunci: Rumah Belajar, sumber belajar, kelas maya, kualitas pembelajaran

ABSTRACT: Utilization of Information and Communication Technology (ICT) has been creating a new model of learning, i.e. online learning or web-based learning. One of the learning webs is Rumah Belajar, with url address of: http:// belajar.kemdikbud.go.id. Now, the problem is how the utilization of Rumah Belajar as a learning resource, a means of virtual classroom, and as a means to improve learning quality is. This study aims to describe the utilization of Rumah Belajar as a learning resource, as a means of virtual classroom, and a 
means to improve the quality of learning. The method applied in this study is literary review of various research results relevant to portal Rumah Belajar. The result shows that Rumah Belajar can be utilized as: (1) a learning resource to get learning content or materials; (2) a means of virtual classes, i.e. to facilitate online learning between learners and teachers at anytime and anywhere; and (3) a means to improve students' learning outcomes which in turn can improve the quality of learning. The conclusion is that the utilization of Rumah Belajar is proved effective to improve the quality of learning. It is therefore recommended that students, teachers, and society, or anyone who wants to learn, can utilize Rumah Belajar.

Keywords: Rumah Belajar, learning resource, virtual class, learning quality.

\section{PENDAHULUAN}

Abad 21 dikenal dengan abad teknologi, di mana berbagai aspek kehidupan berkembang sangat pesat, terutama bidang pendidikan. Guru maupun peserta didik dituntut untuk dapat mengoperasikan dan menggunakan teknologi sebaik-baiknya dalam proses pembelajaran. Pembelajaran berbasis teknologi dapat diselenggarakan dalam berbagai model dengan memanfaatkan Teknologi Informasi dan Komunikasi (TIK) melalui audio/radio, video/ TV, multimedia, serta pembelajaran dengan menggunakan media komputer dan internet (interconnection and networking). Pembelajaran dengan menggunakan media komputer dan internet merupakan salah satu alternatif yang sangat potensial, di mana kebutuhan pendidikan yang telah mengglobal menuntut adanya percepatan dan perluasan akses yang tak terbatasi.

Perkembangan TIK membawa perubahan dramatis dalam semua aspek kehidupan, termasuk di bidang pendidikan. Penerapan TIK telah melahirkan model baru dalam pembelajaran (Kusnohadi, 2014), misalnya munculnya online learning atau pembelajaran berbasis web. Online learning merupakan model pembelajaran dengan menggunakan jaringan internet sebagai saluran utama komunikasi dan interaksi pembelajaran dan biasanya memanfaatkan web. Fenomena tersebut telah menjadi tren dan secara berangsur-angsur menggeser model pembelajaran konvensional. Kondisi ini sesuai dengan hasil survei yang digelar oleh DailySocial.id bekerja sama denganJakPat terhadap 1.023 responden yang diambil dari seluruh populasi Indonesia, yang menunjukkan bahwa lebih dari separuh responden $(56,11 \%)$ pernah mendengar istilah kelas belajar online. Namun demikian, sebagian besar di antara mereka belum pernah mencobanya $(78,30 \%$ untuk kelas belajar online lokal dan $79,77 \%$ untuk kelas belajar online luar negeri).Dari sekian banyak penyedia layanan kelas belajar online dari luar negeri, berikut ini yang lebih populer: Duolingo(9,17\%), Open Courseware $(4,68 \%)$,Coursera- $(4,29 \%)$, dan Khan Academy (4\%). Sementara untuk penyedia layanan lokal dari Indonesia, yang lebih populer adalah IndonesiaX $(7,62 \%)$, Kelase $(3,42 \%)$, dan BangsaCerdas $(7,92 \%)$ (Wahyu Hidayat, tekno.liputan6.com).

Dalam rangka meningkatkan layanan dan kebutuhan sumber belajar bagi peserta didik, diadakan program layanan TIK untuk pembelajaran seperti bahan belajar interaktif dilengkapi dengan media pendukung gambar, animasi, video, dan simulasi. Kementerian Pendidikan dan Kebudayaan meluncurkan program layanan TIK pembelajaran melalui media berbasis web dan televisi pada tanggal 15 Juli 2011. Media berbasis web berupa Portal Rumah Belajar untuk semua masyarakat Indonesia dan bahan pembelajaran berbasis televisi yang 
diperuntukkan bagi peserta didik berkebutuhan khusus (http://inovasi.lan.go.id/ -index.php?r=inovasi).

Portal Rumah Belajar merupakan portal pembelajaran resmi Kementerian Pendidikan dan Kebudayaan, dengan alamat url http:// belajar.kemdikbud.go.id. Portal Rumah Belajar menyediakan fasilitas Sumber Belajar, Kelas Maya, Pengembangan Keprofesian Berkelanjutan, Kurikulum 2013, dan Jelajah Luar Angkasa. Rumah Belajar dapat dimanfaatkan peserta didik, guru, dan masyarakat luas (Imanuddin, dkk., 2014). Portal ini menyediakan berbagai bahan belajar serta fasilitas komunikasi dan interaksi antar komunitas pendidikan, bahan belajar untuk guru, bahan belajar untuk peserta didik, wahana aktivitas komunitas (forum), bank soal, dan katalog media pembelajaran. Portal Rumah Belajar ini ditujukan untuk peserta didik, guru, dan masyarakat luas, atau siapa pun yang mau belajar (Nurhayati, 2012).

Fitur-fitur yang tersedia di portal Rumah Belajar antara lain, yaitu: sumber belajar, BukuSekolah Elektronik (BSE), bank soal, laboratorium maya, peta budaya, wahana jelajah angkasa, pengembangan keprofesian berkelanjutan, dan kelas maya. Selain fitur utama, terdapat juga konten-konten terbaru serta fitur-fitur pendukung seperti karya komunitas (materi pembelajaran dari komunitas), karya guru (materi pembelajaran dari guru), dan karya bahasa dan sastra (pustaka bahasa dan sastra).

Kehadiran Portal Rumah Belajar di dunia maya (internet) menambah khasanah sumber belajar bagi dunia pendidikan di Indonesia. Portal Rumah Belajar ini memudahkan guru membuat pembelajaran menjadi lebih menarik, karena tersedia berbagai komponen yang diperlukan untuk pembelajaran baik di kelas maupun di luar kelas, terutama penugasan kepada peserta didik agar peserta didik sedini mungkin mengenal teknologi (Warsihna, 2012). Oleh karena itu, Portal Rumah Belajar ini memfasilitasi terjadinya pembelajaran berbasis teknologi atau pembelajaran online.

Pembelajaran dengan memanfaatkan Portal Rumah Belajar ini merupakan salah satu model pembelajaran online atau pembelajaran berbasis web. Oleh karena itu, pembelajaran berbasis webadalah kegiatan atau proses pembelajaran yang sebagian atau seluruhnya dilaksanakan dengan memanfaatkan website atau portal sebagai sarana penyampaian bahan belajar maupun sarana interaksi dan komunikasi (Warsita, 2017a), misalnya kegiatan pembelajaran yang memanfaatkan fitur sumber belajar, fitur kelas maya, fitur laboratorium maya, dan lain-lain.

Dewasa ini, kegiatan pembelajaran tidak hanya terjadi di dunia nyata atau dalam ruangan kelas saja, tetapi juga dapat terjadi di dunia maya yang lebih dikenal dengan istilah e-learning seperti pada Portal Rumah Belajaryang merupakan $L$ e arning Management System (LMS). Hasil penelitian mengenai model manajemen pelatihan berbasis partisipatif untuk meningkatkan profesionalitas guru dalam mendayagunakan e-Learning pada Portal Rumah Belajar menunjukkan bahwa pengembangan model manajemen pelatihan berbasis partisipatif sangat efektif untuk meningkatkan profesionalitas Guru Kimia dalam mendayagunakan e-learning Portal Rumah Belajar. Selain itu, keefektifan model dapat diketahui dari peningkatan kemampuan peserta pelatihan dalam mendayagunakan elearning Portal Rumah Belajar(Kusumaningrum, dkk., 2014). Oleh karena itu, fitur kelas maya portal Rumah Belajar dapat dimanfaat oleh guru dalam upaya untuk meningkatkan kualitas pembelajaran.

Ada beberapa hasil penelitian sebelumnya mengenai sejauh mana kepuasan pengguna memanfaatkan Portal Rumah Belajar dalam mendukung kegiatan pembelajaran. Hasil pengukuran kualitas Portal Rumah Belajar dengan menggunakan metode Webqual 4.0 menunjukkan variabel usability dan kualitas informasi tidak berpengaruh dan tidak signifikan terhadap kepuasan pengguna Portal Rumah Belajar. Hal ini kurang begitu dirasakan manfaatnya oleh peserta didik dan guru karena mereka belum memanfaatkan Portal Rumah Belajar secara maksimal dikarenakan tidak adanya sosialisasi dan pelatihan pemanfaatan Portal Rumah Belajar (Yudiastuti \& Megawati. 2015). 
MetodeWebQual 4.0 terdiri atas tiga kategori, yaitu: 1) usability adalah mutu yang berhubungan dengan rancangan situs; 2) kualitas informasi adalah mutu dari konten atau materi pembelajaran yang terdapat pada situs; dan 3) interaksi pelayanan adalah mutu dari interaksi pelayanan yang dialami oleh pengguna ketika pengguna menyelidiki atau memanfaatkan situs lebih dalam.

Hasil penelitian lain tentang pengaruh penerimaan teknologi dengan kegunaan web, studi kasus Portal Rumah Belajar, menunjukkan bahwa hanya variabel kebergunaan web atau usability web yang berpengaruh signifikan terhadap kepuasan pengguna Portal Rumah Belajar. Sementara variabel penerimaan informasi dan penerimaan teknologi internet tetap memiliki pengaruh meski tidak signifikan. Pengaruh yang signifikan dari kebergunaan web ini sesuai dengan konsepnya (Chabibie, 2012). Dengan demikian, kualitas layanan Portal Rumah Belajar ini sangat berpengaruh pada tingkat kebermanfaatan pengguna, yaitu peserta didik, guru, dan masyarakat luas.

Berdasarkan hasil-hasil penelitian sebelumnya di atas dan fitur-fitur yang tersedia di Portal Rumah Belajar, penelitian kepustakaan atau studi literatur ini fokus hanya pada pemanfaatan fitur sumber belajar dan fitur kelas maya serta perannya dalam meningkatkan kualitas pembelajaran. Oleh karena itu, rumusan permasalahannya adalah bagaimana pemanfaatan portal Rumah Belajar sebagai sumber belajar, sebagai sarana pembelajaran kelas maya (pembelajaran online), dan sebagai sarana untuk meningkatkan kualitas pembelajaran. Tujuanpenelitian kepustakaan atau studi literatur ini adalah untuk mendiskripsikan atau menggambarkan pemanfaatan portal Rumah Belajar sebagai sumber belajar, sebagai sarana pembelajaran kelas maya, dan sarana untuk meningkatkan kualitas pembelajaran.

\section{METODA}

Metode penelitian yang digunakan dalam penelitian ini adalah metode deskriptif. Penelitian deskriptif dimaksudkan untuk menggambarkan secara sistematis fakta dan karateristik obyek atau subyek yang diteliti secara tepat (Darmadi, 2011). Teknik pengumpulan data dan informasinya melalui studi literatur. Pengumpulan data dilakukan dengan mengkaji hasil-hasil penelitian sejenis yang sudah ada sebelumnya serta mengkaji aplikasi portal Rumah Belajar. Analisis data dilakukan secara deskriptif dan menyajikannya secara deskriptif.

\section{HASIL DAN PEMBAHASAN}

\section{Pemanfaatan Portal Rumah Belajar sebagai Sumber Belajar}

Fitur sumber belajar Portal Rumah Belajar memuat bahan-bahan belajar yang dapat digunakan oleh guru dan peserta didik sebagai sumber belajar di sekolah maupun di rumah. Adapun yang dimaksud bahan belajar adalah segala bentuk konten baik teks, gambar, foto, audio, video, animasi, simulasi, dan lain-lain yang dapat digunakan untuk belajar (Tasri, 2011). Konten dalam fitur sumber belajar sudah sangat lengkap. Bahan belajar mulai dari SD sampai SMA/SMK ada di sini termasuk semua mata pelajaran dan semua topik.

Ditinjau dari subjeknya, bahan belajar dapat dikategorikan menjadi dua jenis, yakni bahan belajar yang sengaja dirancang untuk belajar dan bahan yang tidak dirancang namun dapat dimanfaatkan untuk belajar (Kusnandar, 2008). Banyak bahan belajar yang tidak dirancang untuk belajar, namun dapat digunakan untuk belajar, misalnya video di Youtube, CD-Rom, VOD, Potcast, berita, dan lain-lain. Karena sifatnya yang tidak dirancang, pemanfaatan bahan belajar seperti ini perlu diseleksi dan dipilih sesuai dengan tujuan pembelajaran.

Bahan belajar yang dirancang adalah bahan belajar yang dengan sengaja disiapkan untuk keperluan belajar, misalnya pembuatan modul online yang disiapkan untuk belajar mandiri peserta didik secara online. Sekurangkurangnya ada empat ciri utama bahan belajar yang sengaja dirancang, yakni: adanya tujuan pembelajaran yang jelas, ada sajian materi secara lengkap, ada petunjuk belajar, dan ada evaluasi keberhasilan belajar (Tasri, 2011). Bahan belajar yang terdapat di 
fitur sumber belajar Portal Rumah Belajar ini termasuk kategori pada bahan belajar yang sengaja dirancang untuk belajar. Oleh karena itu, bahan belajar adalah kemasan materi pembelajaran yang dikembangkan sedemikian rupa sehingga peserta didik dapat mempelajari secara mandiri dan memanfaatkan dalam proses pembelajaran. Bahan belajar yang terdapat di fitur sumber belajar Portal Rumah Belajar ini dikembangkan berbasis web. Bahan belajar berbasis web adalah adalah bahan belajar yang disiapkan, dijalankan, dan dimanfaatkan dengan media web (Tasri, 2011). Bahan belajar berbasis web ini sering juga disebut bahan belajar berbasis internet atau bahan belajar online (Kusnandar, 2008). Oleh karena itu, pembelajaran berbasis web yang memanfaatkan sumber belajar Portal Rumah Belajar ini dikembangkan secara khusus untuk memfasilitasi terjadinya pembelajaran online antara peserta didik dan guru kapan saja dan di mana saja. Bahkan, ke depan bisa untuk mendukung model pembelajaran abad 21.

Pengembangan bahan belajar berbasis web hendaknya dilakukan secara sistematis dan berorientasi pada peserta didik. Pengembangan bahan belajar berbasis web ini dapat pula dikelompokkan ke dalam tiga tahap besar, yaitu: 1) tahap perancangan; 2) tahap produksi; dan 3) tahap evaluasi. Adapun tahap pengembangan bahan belajar berbasis web ini dimulai dengan penyusunan garis besar isi media (GBIM), pembuatan flowchart, penulisan naskah, pelaksanaan produksi, dan evaluasi.

Terdapat tiga karakteristik utama yang merupakan potensi besar bahan belajar yang terdapat di fitur sumber belajar Portal Rumah Belajar, yakni: menyajikan multimedia (teks, grafis, audio, video, animasi, simulasi dan interaktif), menyimpan, mengolah, dan menyajikan infromasi, dan hyperlink (Kusnandar, 2008). Karena sifatnya yang online, bahan belajar yang terdapat di fitur sumber belajar Portal Rumah Belajar ini mempunyai karakteristik khusus sesuai dengan karakteristik web itu sendiri. Salah satu karakteristik yang paling menonjol dari web adalah adanya fasilitas hyperlink dan hypermedia. Hyperlink memungkinkan suatu subjek materi terhubung atau nge-link ke subjek lain tanpa ada batasan fisik dan geografis, selama subjek yang bersangkutan tersedia pada web. Dengan adanya fasilitas hyperlink dan hypermedia, sumber belajar Portal Rumah Belajar ini menjadi sangat kaya. Search engine sangat membantu untuk mencari subjek yang dapat dijadikan koneksi (link).

Bahan belajar di fitur sumber belajar Portal Rumah Belajar ini menyajikan multimedia. Adapun multimedia pembelajaran merupakan kombinasi yang terintegrasi dari berbagai media yang terdiri dari teks, grafis, foto, animasi, suara dan video yang dimanfaatkan untuk kegiatan pembelajaran (Warsita, 2017b). Oleh karena itu, ada tiga aspek yang harus ada dalam multimedia pembelajaran, yaitu: a) adanya lebih dari satu media yang konvergen; b) interaktif; dan c) mandiri, dalam pengertian memberi kemudahan dan kelengkapan materi pembelajaran sedemikian rupa sehingga peserta didik dapat menggunakan untuk belajar mandiri tanpa bimbingan orang lain.

Portal Rumah Belajar sebagai sumber belajar berarti Rumah Belajar dapat dijadikan sebagai sumber untuk mendapatkan berbagai informasi, data-data, gagasan-gagasan atau ide-ide yang berkaitan dengan materi pembelajaran baik dalam bentuk teks, gambar, grafis, audio, video, animasi maupun simulasi. Dengan kata lain, Portal Rumah Belajar dijadikan sebagai sarana untuk memperoleh konten atau bahan belajar. Artinya bahan belajar ini berfungsi sebagai sumber belajar seperti halnya guru dalam pembelajaran. Ketersediaan sumber belajar ini diharapkan dapat dimanfaatkan peserta didik dan guru dalam kegiatan pembelajaran di manapun dan kapanpun baik secara terpisah maupun dalam bentuk gabungan. Bahan belajar yang terdapat di fitur sumber belajar Portal Rumah Belajar ini diharapkan bisa mewakili sosok pendidik (guru) dan keberadaannya didesain untuk membelajarkan peserta didik. Oleh karena itu, sajian materi dalam bahan belajar harus berorientasi kepada kepentingan belajar peserta didik. Portal Rumah Belajar memuat 
bukan hanya materi pembelajaran, tetapi juga berbagai pola kegiatan yang dapat merangsang, memacu, dan menantang peserta didik untuk belajar dan menilai sendiri kemajuan belajarnya.

Fitur sumber belajar pada Portal Rumah Belajar ini memuat antara lain: RPP, materi pokok, modul online, pendukung BSE, pengetahuan populer, katalog media, bank soal, bahan belajar interaktif, obyek pembelajaran (learning object), dan Video on Demand (VoD). Selain itu, untuk memperkaya sumber belajar di Portal Rumah Belajar ini, telah terhubung dengan web TV edukasi, radio suara edukasi, radio edukasi, Buku Sekolah Elektronik (BSE), dan peta budaya nusantara.

Dalam perkembangannya, fitur sumber belajar pada Portal Rumah Belajar ini banyak memuat konten dalam bentuk obyek pembelajaran (learning object). Suatu obyek pembelajaran (learning object) merupakan penggalan atau kepingan terkecil dari materi pembelajaran sebagai pengetahuan. Istilah obyek bermakna mandiri dan dapat digunakan kembali. Objek ajar merupakan hasil kerja keras para ahli TIK yang berupaya untuk berpikir lintas keilmuan agar dapat memfasilitasi materi ajar secara online (Salma, dkk., 2014). Dengan ketersediaan jaringan, obyek ajar selanjutnya 'diwadahi' secara khusus dalam suatu template, suatu software, misalnya Learning Content Management System (LCMS).

Learning Object (LO) adalah segala entitas, digital atau non-digital, yang dapat digunakan untuk pembelajaran. Learning object merupakan satuan terkecil bahan belajar yang memuat satu tujuan (objective) pembelajaran yang spesifik. Ibarat sebuah puzzle, learning object adalah potongan puzzle yang dapat dipasang-pasangkan dengan potongan lainnya sehingga membentuk sebuah bangun tertentu. Learning object memiliki karakter memuat gagasan tunggal, interoperable, dan reusable (Kusnandar, 2013). Dengan karakterisktik ini, fitur sumber belajar pada portal Rumah Belajar memuat learning object, dengan tujuan untuk dapat dimanfaatkan oleh guru atau peserta didik dalam pengembangan pembelajaran yang kreatif dan inovatif.
Artinya, learning object dapat dimanfaatkan sebagai media pembelajaran, baik secara langsung ataupun diadaptasi dalam berbagai aktivitas pembelajaran yang kreatif dan inovatif.

Beberapa keuntungan pengembangan bahan belajar fitur sumber belajar pada portal Rumah Belajar dengan pendekatan learning object, yaitu: (1) LO relatif tidak berubah meskipun kurikulum senantiasa berubah, sehingga investasi yang dikeluarkan untuk mengembangkan LO dapat dimanfaatkan untuk waktu yang lama; (2) apabila LO dikembangkan berdasarkan target bersama, dapat terjadi sinergi dan percepatan penyediaan bahan belajar; pengembangan LO dapat menjadi sarana aktivitas guru dan peserta didik dalam mengembangkan model-model pembelajaran inovatif berbasis TIK; (4) LO dapat menjadi sarana berbagi (share) sumber daya, di mana hal ini merupakan bentuk aktual dari pembelajaran kolaboratif sesuai dengan prinsip pembelajaran abad 21; (5) LO sangat membantu guru ataupun peserta didik dalam mengembangkan bahan belajar yang lebih lengkap sesuai dengan kebutuhan; dan 6) LO dapat mendorong kreativitas, baik guru ataupun peserta didik.

Fitur sumber belajar pada portal Rumah Belajar menyediakan berbagai konten pembelajaran digital baik konten yang sesuai kurikulum ataupun materi pengayaan. Semua fitur portal Rumah Belajar tersebut dapat dijadikan sebagai sumber belajar untuk peserta didik jenjang PAUD, SD/MI, SMP/MTs, SMA/MA, dan SMK. Adapun pemanfaatan sumber belajar ini dapat dilakukan secara online maupun offline. Selain itu, bahan belajar ini dapat di unduh (download) dan digunakan sesuai kebutuhan belajar.

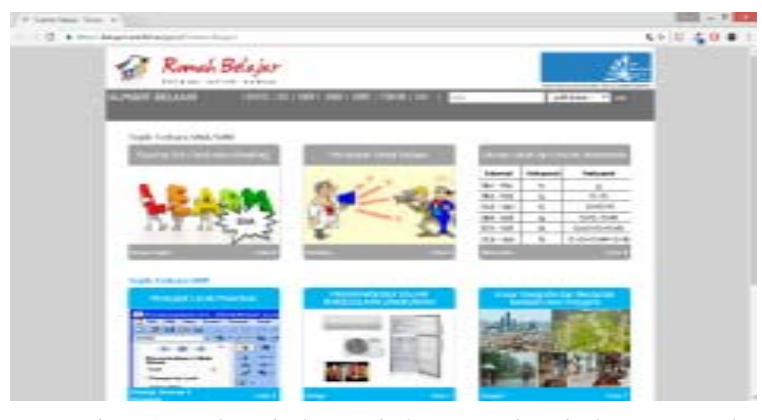

Gambar 1: Bahan belajar di fitur sumber belajar portal Rumah Belajar 
Dalam pemanfaatan fitur Sumber Belajar pada portal Rumah Belajar ini, pendidik dan peserta didik akan mendapatkan informasi materi pelajaran secara komprehensif dan interaktif. Materi bahan belajar disajikan secara sistematis dan terstruktur dengan tampilan yang menarik. Setiap materi akan disajikan secara lengkap mulai dari identitas topik (judul topik, kelas, semester, jenjang pendidikan), kompetensi (kompetensi dasar, kompetensi inti, dan indikator), sinopsis (ringkasan materi), uraian materi (disajikan dengan menggunakan berbagai media teks, gambar, audio, video, animasi, dan simulasi), latihan/tugas, dan tes atau evaluasi hasil belajar (soal dan penilaian secara online). Seluruhnya disajikan dengan multimedia, yaitu media teks, gambar, audio, video, dan animasi, serta permainan (game online) sehingga diharapkan akan memudahkan peserta didik untuk memahami materi pembelajaran.

Efektivitas pemanfaatan sumber belajar ini sesuai dengan hasil penelitian tentang pengaruh pemanfaatan e-learning menggunakan "Portal Rumah Belajar Kemendikbud" terhadap hasil belajar peserta didik pada mata pelajaran IImu Pengetahuan Alam (IPA) di SMP Negeri 1 Lembang Jawa Barat pada materi sumber belajar topik sistem gerak pada manusia menyimpulkan bahwa pemanfaatan e-learning dengan menggunakan "Portal Rumah Belajar Kemendikbud" ini terbukti berpengaruh dalam meningkatkan hasil belajar peserta didik ranah kognitif aspek memahami (C2), menerapkan (C3), dan menganalisis (C4) pada mata pelajaran IPA materi sistem gerak pada manusia (Mulyadi, 2015).

Pemanfaatan e-learning dengan mengunakan portal Rumah Belajar dapat membantu peserta didik dalam memahami materi pembelajaran sulit yang terdapat pada mata pelajaran IPA karena materi yang disajikan di sumber belajar dilengkapi dengan berbagai media teks, grafis, audio, video, dan animasi sehingga peserta didik dapat dengan mudah memahami materi dan mendeskripsikan hal-hal yang abstrak menjadi konkrit (Mulyadi, 2015). Dengan demikian, hasil belajar ranah kognitif pada aspek pemahaman (C2) dapat tercapai dengan baik.

Sedangkan pada hasil belajar ranah kognitif pada aspek penerapan (C3), pemanfaatan sumber belajar pada portal Rumah Belajar dapat membantu dan memudahkan peserta didik dalam menerapkan atau mengaplikasikan dalam kegiatan pembelajaran. Sebagai contohnya adalah bahwa peserta didik bisa dengan mudah menunjukkan rangka penyusun sistem gerak, menentukan fungsi tulang dan sendi, mengilustrasikan fungsi otot dan tulang sendi, menafsirkan fungsi sistem gerak, menafsirkan penyakit yang berhubungan dengan sistem gerak sehingga peserta didik dapat mendeskripsikan sistem gerak pada manusia dan hubungannya dengan kesehatan (Mulyadi, 2015). Hal ini ditunjang kelebihan yang ada di sumber belajar pada portal Rumah Belajar yakni adanya penjelasan berupa teks yang disertai dengan visual berupa gambar, bagan, video, dan animasi yang dapat dijadikan sebagai pengganti dari kegiatan simulasi.

Selain itu, pemanfaatan sumber belajar portal Rumah Belajar ini ternyata berpengaruh terhadap hasil belajar ranah kognitif pada aspek analisis (C4). Artinya, berbagai aktivitas belajar yang diberikan di sumber belajar ini dapat mendorong peserta didik untuk melakukan diskusi, mengerjakan latihan, tugas, dan lain lain. Oleh karena itu, dengan memanfaatkan sumber belajar pada portal Rumah Belajar ini peserta didik dituntut untuk aktif dalam menyimpulkan, menganalisis, dan mengurutkan fungsi serta kelainan pada sistem gerak pada manusia (Mulyadi, 2015). Berdasarkan hal tersebut, pemanfaatkan sumber belajar portal Rumah Belajar dapat meningkatkan hasil belajar peserta didik, yaitu dapat memahami dan menganalisis konsep, dan juga mengaplikasikan konsep tersebut. Dengan demikian, peserta didik dapat mengerjakan latihan-latihan, tugas, tes, dan mengembangkan kreativitasnya setelah mereka dapat menganalisis apa yang telah dipelajarinya.

Akhirnya, dengan adanya bahan belajar di fitur sumber belajar pada portal Rumah Belajar ini, guru, peserta didik, dan 
masyarakat mendapatkan berbagai fasilitas dan sumber belajar yang berkualitas. Sebagai contohnya adalah bahwa peserta didik dapat dimanfaatkan untuk belajar mandiri atau pengayaan pembelajaran di kelas. Sedangkan bagi guru, pemanfaatan sumber belajar portal Rumah belajar ini dapat digunakan sebagai pengembangan bahan ajar, media pembelajaran di kelas, atau bahan referensi pembelajaran. Selain itu, guru dapat memanfaatkan portal Rumah Belajar, yaitu sebagai sumber belajar saat pembelajaran di kelas, sebagai penugasan untuk belajar mandiri, dimanfaatkan pada saat jam kosong (guru tidak hadir), dan sebagai sarana epembelajaran (e-learning) (Martiningsih, 2017).

Bagi masyarakat umum (misalnya orang tua siswa), pemanfaatan sumber belajar portal Rumah belajar ini dapat digunakan sebagai bahan belajar mandiri, pengayaan agar bisa mendampingi belajar putra/putrinya sesuai dengan tingkat dan jenjang pendidikan. Bahkan sumber belajar portal Rumah Belajar ini dapat digunakan sebagai sarana belajar sepanjang hayat.

Pemanfaatan sumber belajar portal Rumah Belajar sebagai suplemen pembelajaran di kelas terbukti sangat efektif. Hasil penelitian tentang pengaruh pembelajaran Direct Instruction dengan suplemen portal Rumah Belajar (situs eLearning Kemdikbud) terhadap hasil belajar peserta didik pada materi sistem saraf manusia di MAN 11 Jakarta Selatan tahun ajaran 2013/2014 dengan metode kuasi eksperimen diperoleh $t_{\text {hitung }}$ sebesar 8,26 dan $t_{\text {tabel }}$ pada taraf signifikan $5 \%$ sebesar 1,99 sehingga $t_{\text {hitung }}>t_{\text {tabel }}$. Hal tersebut menunjukkan bahwa terdapat pengaruh pembelajaran direct instruction dengan suplemen portal Rumah Belajar (situs e-learning Kemdikbud) terhadap hasil belajar pada materi sistem saraf manusia (Ilmy, 2014). Artinya, bahan belajar di fitur sumber belajar pada portal Rumah Belajar ini dapat dimanfaatkan atau digunakan oleh guru atau peserta didik di mana saja dan kapan saja dengan syarat terdapat koneksi internet. Strategi pemanfaatan sumber belajar portal Rumah Belajar oleh guru harus direncanakan, diidentifikasi, dan dipilih terlebih dahulu sesuai dengan kebutuhan guru, kemudian dituangkan dalam Rencana Pelaksanaan Pembelajaran (RPP), dan selanjutnya dimanfaatkan di kelas sebagai media pembelajaran di kelas, dan digabungkan dengan penerapan berbagai model/ pendekatan pembelajaran yang sesuai dengan tujuan pembelajaran yang akan dicapai.

Langkah-langkah pemanfaatan sumber belajar portal Rumah Belajar dalam pembelajaran, yaitu: (1) memilih materi sesuai topik yang akan disampaikan; mengidentifikasi konten materi, media teks/ audio/video, simulasi dan evaluasi/latihan yang tersedia di sumber belajar sesuai topik yang dipilih untuk dipelajari dan dicermati, bagian mana yang akan disampaikan ke peserta didik; (3) mengunduh materi (jika akan disampaikan secara offline) atau meng-copy alamat link materi sumber belajar; (4) menyusun RPP terintegrasi TIK yang memanfaatkan Sumber Belajar, dengan cara memasukkannya konten materi, media, simulasi dan atau evaluasi/latihan ke dalam RPP dan menggabungkannya dengan model pembelajaran modern yang sesuai; dan (5) menerapkan RPP tersebut di kelas.

Secara sistematis, pemanfaatan sumber belajar portal Rumah Belajar dalam kegiatan pembelajaran di kelas, yaitu: (1) buka portal Rumah Belajar dengan alamat: https:// belajar.kemdikbud.go.id kemudian pilih fitur sumber belajar atau langsung https:// belajar.kemdikbud.go.id/sumberbelajar; (2) pilih jenjang pendidikan misalnya SD/SMP/ SMA/-SMK; (3) pilih jenjang kelas (misalnya kelas $4,5,6,7,8,9, \ldots)$; (4) pilih mata pelajaran(misalnya Bahasa Indonesia, Bahasalnggris...dan sebagainya); (5) pilih dan pelajari topik-topiknya yang tersedia; (6) konsultasikan dengan kurikulum (lihat kesesuaian dengan Kompetensi Dasar (KD), Kompetensi Inti (KI), tema, dan sebaginya); (7) integrasikan ke dalam RPP; dan (8) manfaatkan dalam kegiatan pembelajaran di kelas (Warsita, 2017).

Pemanfaatan fitur sumber belajar portal Rumah Belajar ini merupakan sarana untuk meningkatkan kualitas pembelajaran. Hal ini sesuai dengan hasil penelitian mengenai 
bagaimanakah penerapan Portal Rumah Belajar dapat meningkatkan prestasi belajar Matematika materi irisan dan gabungan dua himpunan di kelas VIIA SMP Muhammadiyah 1 Surabaya tahun ajaran 2012/2013. Sebelum tindakan, peserta didik yang tuntas belajar sebanyak 22 orang $(73,3 \%)$, pada Siklus I yang tuntas sebanyak 23 orang $(76,7 \%)$, sedangkan pada Siklus II yang tuntas sebanyak 28 orang $(93,3 \%)$. Dilihat dari ketuntasan belajar, terdapat peningkatan prestasi belajar peserta didik. Selain itu, penggunaan portal Rumah Belajar terbukti dapat meningkatkan kualitas pembelajaran Matematika materi irisan dan gabungan dua himpunan sebelum tindakan sebesar 2.00, sedang pada siklus I sebesar 3.00 dan pada Siklus II sebesar 4.50. Dengan demikian, kualitas pembelajaran dari sebelum tindakan sampai dengan Siklus II terjadi peningkatan (Martiningsih, 2013).

Salah satu kebutuhan guru dalam mempersiapkan kegiatan pembelajaran adalah merancang dan mengembangkan pembelajaran. Portal Rumah Belajar memberikan kesempatan kepada guru untuk mengembangkan inovasi dan meningkatkan kreativitasnya dalam membuat rencana pembelajaran, membuat materi ajar, dan membuka kelas maya melalui fasilitas Kelas Maya serta dilengkapi dengan sumber belajar untuk guru dan peserta didik dalam mendukung terselenggaranya kelas maya (Imanuddin, dkk., 2014).

\section{Pemanfaatan Portal Rumah Belajar sebagai Sarana Pembelajaran Kelas Maya}

Perkembangan TIK telah mempengaruhi perubahan global yang cepat dalam berbagai aspek kehidupan sosial masyarakat. Kini berkat TIK, komponen pendidikan yang memungkinkan terjadinya perubahan, seperti: guru, ruang kelas, bahan belajar, dan lain-lain dapat digandakan atau diperbanyak hingga hampir tak terbatas. Guru, ruang kelas, dan bahan belajar digandakan dengan TIK sehingga ada guru maya (virtualteacher), ruang kelas maya (virtual classroom), dan bahan belajar maya (virtual learning material) hingga evaluasi atau tes online yang tentu saja dapat melayani kebutuhan belajar setiap orang secara nyata.
Keberadaan atau eksistensi komponen pendidikan, yang kurang bermutu atau kurang mampu melayani kebutuhan belajar peserta didik, saat ini benar-benar terancam oleh keberadaan atau eksistensi komponen pendidikan maya/virtual. Sekolah yang buruk terancam oleh sekolah maya, guru yang tidak mampu membelajarkan peserta didik terancam oleh guru maya, dan bahan belajar yang kurang bermutu ditinggalkan dan digantikan oleh bahan belajar maya yang tersedia dan mudah diakses. Kini, orang yang belajar dapat mencari guru, kelas, dan bahan belajar maya serta aneka sumber belajar lainnya yang benar-benar dapat memenuhi kebutuhannya.

Salah satu fitur utama portal Rumah belajar adalah fitur kelas maya. Fitur kelas maya ini merupakan saran untuk pembelajaran online. Pembelajaran maya (online learning) merupakan model pembelajaran dengan menggunakan jaringan internet sebagai saluran utama komunikasi dan interaksi pembelajaran (Kusnohadi, 2014). Penerapan pembelajaran maya merupakan paradigma positif dan alat baru yang potensial untuk melakukan revolusi dengan memperluas akses terhadap pendidikan (Dykman, 2008). Selain itu, penerapan pembelajaran maya meningkatkan kebebasan belajar, fleksibilitas, adaptasi, dan penerapan prinsip belajar sepanjang hayat.

Kita bisa belajar dengan cara yang beragam, apalagi di zaman yang penuh dengan kemudahan ini. Dahulu, orang belajar melalui pengalaman hidupnya, atau pengalaman orang lain, atau mereka belajar dengan melakukan sesuatu. Sekolah adalah tempat yang terbaik untuk belajar. Namun, sekolah tidak bisa membatasi seseorang untuk belajar. Sekolah sebaiknya menjadi tempat belajar. Oleh karena itu, sekolah tidak bisa dibatasi oleh ruang dan waktu. Di era yang kita sebut sebagai era TIK yang ditandai dengan fenomena dunia maya (cyber) ini, konsep sekolah yang tidak dibatasi oleh ruang dan waktu itu bisa sangat mudah diimplementasikan dengan memanfaatkanTIK. Misalnya cukup klik "Rumah Belajar", kita bisa mendapatkan berbagai manfaat mulai dari kelas maya hingga ilmu luar angkasa. Selain 
itu, kita bisa belajar mulai peta budaya sampai pada jelajah ruang angkasa.

Kelas maya merupakan salah satu fitur di portal Rumah Belajar yang dikembangkan khusus untuk memfasilitasi terjadinya pembelajaran virtual antara peserta didik dan guru kapan saja dan di mana saja. Kelas maya merupakan kelas virtual sehingga guru dapat mengajar peserta didik dari jarak jauh. Pada waktu tertentu yang terjadwal oleh guru, peserta didik dapat mengikuti pembelajaran virtual dengan guru melalui tool komunikasi sincronous (chat, video conference, audio conference, desktop sharing, whiteboard, dll). Selain itu, peserta didik dapat belajar secara asincronous mempelajari materi ajar secara mandiri. Strategi pembelajaran yang dikembangkan di kelas maya yaitu strategi pembelajaran yang bersifat konstruktivistik, pembelajaran aktif, dan berpusat pada peserta didik untuk mendorong keterampilan peserta didik.

Komponen pembelajaran tatap muka serupa dengan pembelajaran maya (online learning), unsur pembedanya terletak pada setting lingkungan (Kusnohadi, 2014).Salah satu contohnya adalah bahwa fitur kelas maya memungkinkan guru dan peserta didik berkomunikasi lewat dunia maya. Guru dapat memberikan materi dengan membuat kelas maya, kemudian peserta didik dapat mengikuti kelas tersebut layaknya seperti pembelajaran di kelas konvensional, hanya saja kelas maya ini dilakukan secara online. Jadi, peserta didik dan guru dapat menggunakan fitur ini kapan saja tanpa harus terikat aturan jam belajar seperti pada pembelajaran di sekolah. Sebelum menggunakan fitur ini, kita harus login terlebih dahulu, bisa menggunakan username dan password yang sudah ada.

Kelas maya merupakan salah satu fitur di Portal Rumah Belajar yang dibangun untuk menghadapi tantangan pendidikan abad 21 ini yaitu pendidikan dengan proses pembelajaran yang interdisiplin dan holistik; mampu menyelesaikan dan beradaptasi dengan berbagai permasalahan; proses pembelajaran berpusat pada peserta didik, partisipatif, dan interaktif; serta berbasis penelitian dan berorientasi kerja; koheren, progresif, dan bercermin pada lingkungan.
Proses pembelajaran ini dapat dijalankan apabila didukung dengan pemanfaatan TIK sebagai alat bantu.

Peran guru dalam proses pembelajaran yang mengintegrasikan TIK diharapkan sebagai fasilitator, kolaborator, mentor, pelatih, pengarah, dan teman belajar serta dapat memberikan pilihan dan tanggung jawab yang besar kepada peserta didik untuk mengalami peristiwa belajar. Sementara itu, peran peserta didik dalam proses pembelajaran yang mengintegrasikan TIK memungkinkannya menjadi partisipan aktif, yaitu menghasilkan dan berbagi (sharing) pengetahuan/ keterampilan, serta berpartisipasi sebanyak mungkin sebagaimana layaknya seorang ahli, belajar mandiri secara individu, dan berkolaboratif dengan peserta didik lain. Semua proses pembelajaran tersebut disediakan dalam fitur Kelas Maya Rumah Belajar. Ada dua hal yang perlu dilakukan guru di Kelas Maya, yaitu membuat materi ajar dan mengelola kelas maya.

Tugas dan peranan guru dalam menerapkan Kelas Maya untuk pembelajaran online, yaitu: (1) harus menguasai perangkat teknologi tersebut sebagai alat utama kegiatan pembelajaran; (2) merancang konten pembelajaran yang sesuai dengan lingkungan online; (3) mengelola sumber belajar; (4) membangun kemandirian belajar peserta didik; (5) menciptakan komunikasi multi arah; dan (6) membangun secara interaksi aktif (Kusnohadi, 2014). Tugas dan peranan guru selanjutnya adalah mengontrol kegiatan belajar, membantu kesulitan belajar, menjamin hasil belajar berkualitas, mengevaluasi pembelajaran, dan mengawal/ membimbing peserta didik hingga kelulusan.

Pembelajaran secara maya/virtual telah menjadi kecenderungan baru yang mendorong setiap orang untuk terlibat di dalamnya. Pembelajaran secara virtual benarbenar telah menjadi bagian kehidupan seharihari, khususnya bagi generasi muda. Belajar dengan memanfaatkan dunia maya, kini benar-benar menjadi kenyataan. Hal ini sesuai dengan hasil penelitian mengenai persepsi guru terhadap salah satu fitur portal Rumah Belajar, yaitu fitur Kelas Maya (virtual class), khususnya persepsi guru terhadap 
tampilan Kelas Maya, dilihat dari kemudahan memanfaatkannya, keuntungan memanfaatkannya, hambatan yang dihadapi dalam memanfaatkannya, dan pengaruhnya pada peningkatan kualitas pembelajaran. Hasilnya menunjukkan bahwa Kelas Maya menarik dari segi tampilan dan mudah digunakan dari sisi navigasi. Namun, tampilan perlu dibuat lebih sederhana terutama terkait prosedur ketika akan membuat materi pembelajaran. Keuntungan memanfaatkan Kelas Maya antara lain yaitu bisa digunakan kapan saja dan di mana saja. Hambatannya adalah terbatasnya sarana dan prasarana serta rendahnya kemampuan guru dalam menggunakan perangkat TIK (Kurniawan, 2017). Oleh karena itu, pemanfaatan Kelas Maya ini merupakan sarana untuk peningkatan kualitas pembelajaran.

Pembelajaran dengan Kelas Maya adalah sebuah lingkungan belajar berbasis web yang memanfaatkan TIK khususnya jejaring pembelajaransosial untuk pembelajaran dan manajemen kelas. Pembelajaran denganKelas Maya adalah peserta didik dapat belajar mandiri yang berbasiskan web atau social media learning (Simanjuntak, 2014). Pada Kelas Maya ini, peserta didik akan mendapatkan materi, tugas, dan tes secara online. Sedangkan guru akan memperoleh kemudahan dalam memeriksa tugas dan menilai hasil ujian peserta didik, terutama hasil ujian peserta didik akan dinilai secara otomatis dan online.

Menurut Jalaludin Rakhmat (2014:1), karakteristik pembelajaran Kelas Maya yaitu: (1) peserta didik sering memegang kendali, mereka tidak suka belajar di sekolah, tapi mereka lebih suka belajar di mana saja dengan menggunakan perangkat digital' (2) mereka senang pilihan, misalnya dalam mengerjakan tugas mereka lebih senang menggunakan teknologi; 3) mereka bekerja secara sosial dan berorientasi pada kelompok, rata-rata mereka bekerja dalam jejaring sosial, dan sangat berkolaboratif (Simanjuntak, 2014).

Kelas Maya portal Rumah Belajar merupakan suatu learning management system (LMS) untuk memfasilitasi pembelajaran secara virtual kapan saja dan di mana saja. Adapun langkah-langkahdalam memanfaatkan fitur Kelas Maya portal Rumah Belajar adalah sebagai berikut: (1) membuka alamat web http://belajar.kemdikbud.go.id/ Kelas Maya; (2) mendaftar sebagai guru dengan cara mengisi data yang diminta guna memperoleh akun di Kelas Maya; (3) mengelola materi pembelajaran, dengan terlebih dahulu memilih mata pelajaran dan topik; (4) mengaktifkan topik yang sudah dibuat; (5) membuat Kelas Maya dengan terlebih dahulu memilih mata pelajaran; (6) mengelola Kelas Maya; (7) membuka kunci topik Kelas Maya; dan (8) membuat ujian (Pustekkom, 2013).

\section{Pemanfaatan Rumah Belajar Untuk Peningkatan Kualitas Pembelajaran}

Pembelajaran merupakan suatu sistem yang mempunyai komponen yang saling terkait untuk mencapai suatu tujuan. Salah satu komponen dari sistem pembelajaran adalah sumber belajar yang dapat dipergunakan dalam kegiatan pembelajaran (Warsita, 2012). Adapun sumber belajar yang dirancang untuk meningatkan kualitas pembelajaran di antaranya adalah sumber belajar yang ada di portal Rumah Belajar. Kegiatan pembelajaran memerlukan interaksi antara peserta didik dengan sumber belajar. Agar diperoleh hasil yang maksimal dengan tingkat interaksi yang tinggi, proses interaksi perlu dikembangkan secara sistematik dengan memanfaatkan keunggulan sumber belajar berbasis web, yaitu dapat menyajikan multimedia dan hyperlink.

Pengembangan proses interaksi dengan sumber belajar adalah merupakan suatu aktivitas dalam memanfaatkan sumber belajar. Aktivitas yang tinggi hendaknya memanfaatkan sumber belajar yang tersedia secara online terutama sumber belajar di Portal Rumah Belajar.

Bahan belajar yang terdapat di fitur sumber belajar Portal Rumah Belajar yang dikembangkan sesuai dengan kurikulum yang berlaku ini sangat membantu keberhasilan suatu proses pembelajaran. Konten yang ada di Portal Rumah Belajar disajikan dengan menampilkan berbagai media teks, gambar, audio, video, animasi maupun simulasi, dan 
permainan (game online). Selain itu, materinya disajikan secara terstruktur mulai dari kompetensi, uraian materi, latihan dan tugas, serta evaluasi hasil belajar secara online, baik guru maupun peserta didik bisa lebih memperdalam dan memperkaya wawasannya. Dengan demikian, kemampuan guru dalam menyampaikan materi pelajaran akan lebih tinggi dan memanfaatkan sumber belajar berbasis web dan metode yang lebih bervariasai. Di sisi lain, kemampuan peserta didik dalam memahami pelajaran juga akan lebih mudah serta peserta didik akan lebih aktif dan kreatif terlibat dalam proses pembelajaran. Oleh karena itu, pemanfaatan Portal Rumah Belajar sebagai salah satu sumber belajar diharapkan dapat berperan untuk meningkatkan kualitas pembelajaran.

Pemanfaatan fitur sumber belajar Portal Rumah Belajar ini merupakan sarana untuk meningkatkan kualitas pembelajaran. Hal ini sesuai dengan hasil penelitian Martiningsih (2017) mengenai persepsi pendidik terhadap pemanfaatan Rumah Belajar sebagai sumber belajar dilihat dari kemudahan dipergunakan, kemenarikan, pengaruhnya terhadap pembelajaran, keuntungan memanfaatkannya, dan hambatan yang dihadapi dalam memanfaatkannya dalam pembelajaran di kota Surabaya yang telah mendapatkan sosialisasi dari Duta Rumah Belajar 2017. Hasil penelitiannya menyatakan bahwa Portal Rumah Belajar mudah digunakan, menarik tampilannya, dan pengaruhnya baik terhadap pembelajaran. Keuntungan memanfaatkan Portal Rumah Belajar antara lain, yaitu: (1) sebagai sumber belajar saat pembelajaran di kelas; (2) sebagai penugasan untuk belajar mandiri; (3) dimanfaatkan pada saat jam kosong; dan (4) bermanfaat pula sebagai sarana epembelajaran (e-learning) yang bisa digunakan kapan saja, di mana saja, dan dengan siapa saja. Sedangkan hambatan yang dihadapi di antaranya yaitu terbatasnya sarana dan prasarana serta rendahnya kemampuan pendidik dalam menggunakan perangkat TIK (Martiningsih, 2017). Oleh karena itu, pemanfaatan Portal Rumah Belajar ini sangat berpengaruh terhadap peningkatan kualitas pembelajaran.
Kelas Maya sebagai sarana pembelajaran online diharapkan mampu meningkatkan kualitas pembelajaran. Hasil pembelajaran online menunjukkan bahwa prestasi belajar peserta didik secara online tidak kalah bila dibandingkan dengan peserta didik yang belajar dengan cara biasa. Pembelajaran online juga mampu membangun kemampuan berfikir tingkat tinggi, melatih daya analisis, kolaborasi, dan berkomunikasi pada peserta didik (Kusnohadi, 2014).

Pemanfaatan fitur Kelas Maya Portal Rumah belajar ini merupakan sarana untuk meningkatkan kualitas pembelajaran. Hal ini sesuai dengan hasil penelitian tentang pengaruh media interaktif berbasis Kelas Maya terhadap peningkatan minat dan prestasi belajar peserta didik pada topik konsep getaran gelombang bunyi Kelas XI SMK Negeri Jumo Temanggung - Jawa Tengah yang menunjukkan bahwa peserta didik yang mengikuti pembelajaran menggunakan Kelas Maya memiliki minat dan prestasi belajar yang lebih tinggi dibandingkan dengan peserta didik yang mengikuti pembelajaran menggunakan modul (bahan belajar mandiri tercetak) (Rumiyanti, 2014). Dengan demikian, pembelajaran dengan memanfaatkan fitur Kelas Maya portal Rumah Belajar terbukti mampu meningkatkan minat dan prestasi belajar peserta didik. Pada akhirnya pemanfaatan fitur Kelas Maya portal Rumah Belajar ini menjadi sarana untuk meningkatkan kualitas pembelajaran.

\section{SIMPULAN DAN SARAN}

\section{Simpulan}

Berdasarkan analisis dan pembahasan di atas, dapat disimpulkan bahwa portal Rumah Belajar dengan alamat url: http:// belajar.kemdikbud.go.id ini dapat dimanfaatkan sebagai sumber belajar, sebagai sarana pembelajaran Kelas Maya (pembelajaran online), dan sarana untuk meningkatkan kualitas pembelajaran.

Portal Rumah Belajar sebagai sumber belajar berarti sebagai sarana untuk mendapatkan berbagai informasi, data-data, gagasan-gagasan atau ide-ide yang berkaitan dengan materi pembelajaran baik dalam 
bentuk teks, gambar, grafis, audio, video, animasi maupun simulasi. Dengan kata lain, portal Rumah Belajar dapat dijadikan sebagai sarana untuk memperoleh konten atau bahan belajar.

Fitur Kelas Maya portal Rumah Belajar merupakan salah satu Learning Management System yang dapat dimanfaatkan guru dan peserta didik untuk memfasilitasi terjadinya pembelajaran online antara peserta didik dan guru kapan saja dan di mana saja. Selain itu, portal Rumah Belajar dapat dimanfaatkan sebagai sarana atau layanan pembelajaran maya (online learning). Bahkan portal Rumah Belajar dapat dimanfaatkan untuk sarana meningkatkan prestasi hasil belajar peserta didik yang pada gilirannya dapat meningkatkan kualitas proses pembelajaran. Saran

Disarankan kepada para peserta didik, guru, dan masyarakat luas, atau siapa pun yang mau belajar agar supaya memanfaatkan portal Rumah Belajar. Selain itu, perlu adanya perbaikan tampilan portal Rumah Belajar sehingga lebih menarik, lebih mudah navigasinya, dan lebih banyak lagi konten pembelajarannya.

\section{PUSTAKA ACUAN}

\section{Buku}

Darmadi, H. (2011). Metode Penelitian Pendidikan. Bandung: Penerbit Alfabeta.

Imanuddin, M., dkk.(2014). Top 99 Inovasi Pelayanan Publik Indonesia Tahun 2014, Jakarta: Kementerian Pendayagunaan Aparatur Negara dan Reformasi Birokrasi dan Yayasan Transformasi Kebijakan Publik (Transformasi) dan Yayasan Rajawali.

Nurhayati, A. S. (2012). Pedoman Pemanfaatan Rumah Belajar, Jakarta: Pustekkom Kemdikbud.

\section{Jurnal/prosiding/disertasi/thesis/skripsi}

Chabibie, M. H.. (2012). Pengaruh Penerimaan Teknologi dengan Kegunaan Web Studi Kasus Portal Rumah Belajar http://belajar.kemdikbud. go.id, Jakarta: Tesis Program IImu Komunikasi, Fakultas IImu Sosial dan IImu Politik, Universitas Indonesia.

Dykman, C. A. dan Davis, C. K. (2008). Online Education Forum: Part Two - Teaching Online Versus Teaching Conventionally. Journal of
Information System Education, Vol. 19 (2): 157-164.

Ilmy, N. A.. (2014). Pengaruh Pembelajaran Direct Instruction dengan Suplemen Rumah Belajar (Situs E-Learning Kemdikbud) Terhadap Hasil Belajar Siswa pada Materi Sistem Saraf Manusia, Jakarta: Skripsi, Program Studi Pendidikan Biologi, Jurusan Pendidikan IImu Pengetahuan Alam, Fakultas IImu Tarbiyah dan Keguruan, UIN Syarif Hidayatullah.

Kusnandar.(2013). Pengembangan Bahan Belajar Digital Learning Object, Jurnal Teknodik Vol. 17 - Nomor 1, Maret 2013.

Kusnohadi. (2014). Pendidik Online: Perluasan Tugas dari Kelas Konvensional menuju Kelas Maya, Jurnal Teknodik Vol. 18 - Nomor 3, Desember 2014.

Kusumaningrum, Indah, W.,Wahyu, H., dan Murwatiningsih.(2014). Model Manajemen Pelatihan Berbasis Partisipatif Untuk Meningkatkan Profesionalisme Guru Dalam Mendayagunakan E-Learning Pada Portal Rumah Belajar, Jurnal Penelitian Tindakan Sekolah dan Kepengawasan Vol. 1. No. 2. Oktober 2014 hal 80- 88.

Kurniawan, A. (2017). Persepsi Guru Peserta TOT Propinsi Kepulauan Riau tahun 2015 terhadap Kelas Maya, Jurnal Teknodik Vol. 21 - Nomor 1, Juni 2017.

Martiningsih.(2013). Peningkatan Prestasi Belajar Himpunan melalui Penggunaan Portal Rumah Belajar, Jurnal Teknodik Vol. 17 - Nomor 1 Maret 2013: 34 -45.

Mulyadi, R. (2015). Pengaruh Pemanfaatan ELearning Menggunakan "Portal Rumah Belajar Kemendikbud" Terhadap Hasil Belajar Siswa Pada Mata Pelajaran IImu Pengetahuan Alam: Kuasi Eksperimen di SMPN 1 Lembang Materi Pokok Sistem gerak pada manusia, Bandung: Tesis Program Kurikulum dan Teknologi Pendidikan, FIP Universitas Pendidikan Indonesia.

Rumiyanti. (2014). Pengaruh Media InteraktifBerbasis Kelas Maya Terhadap Peningkatan Minat dan Prestasi Belajar Siswa Pada Konsep Getaran Gelombang Bunyi Kelas XI SMK Negeri Jumo Temanggung. Tesis pada Fakultas Pasca Sarjana Universitas Ahmad Dahlan Yogyakarta.

Salma, D. Istianty, A., dan Ariany, D. (2014). Penerapan Prinsip Desain Pembelajaran dan Learning Object Situs Kelas Maya Mata Kuliah Gizi Terapan, Jurnal Teknodik Vol. 18 - Nomor 1, April 2014, hal 94- 113.

Simanjuntak, D. (2014). Pembelajaran Dengan Kelas Maya Untuk Meningkatkan Mutu dan 
Efisiensi Pendidikan, Jurnal Pendidikan Penabur-No.23/Tahun ke-3/ Desember 2014 hal 78-85.

Yudiastuti, Helda, Megawati. (2015). Mengukur Kualitas portal Rumah Belajar dengan Menggunakan Metode Webqual 4.0, Jurnal Imiah Matrik Vol. 17 No.2, Agustus $2015: 1$ 20.

Tasri, L.(2011). Pengembangan Bahan Ajar Berbasis Web, Jurnal MEDTEK, Volume 3, Nomor 2, Oktober 2011.

Warsita, B. (2012). Pemanfaatan Perpustakaan sebagai Pusat Sumber Belajar untuk Meningkatkan Kualitas Pembelajaran, Jurnal Teknodik Vol. XVI Nomor 2, Juni 2012.

Warsihna, J. (2012). E-learning Melalui Portal Rumah Belajar, Jurnal Teknodik Volume XVI Nomor 1 Maret 2012, hal $73-84$.

\section{Lain-lain}

Hidayat, M. W. Popularitas \& Peluang Platform Kelas Belajar Online di Indonesia, tekno.liputan6.com/ read// popularitas-amppeluang-platform-kelasbelajar-online-diindonesia, di unduh 4 Januari 2018.

Kusnandar. (2008). Pengembangan Bahan Belajar berbasis Web, http://www.teknologi pendidikan.net / $2008 / 02 / 12 /$ pengembanganbahan-belajar-berbasis-web/, di unduh pada 7 Januari 2018.
Lembaga Administrasi Negara RI, Portal Rumah Belajar, http://inovasi.lan.go.id/index. php?r=inovasi/read\&id=62, diunduh pada 6 Januari 2018.

Martiningsih.(2017). Persepsi Pendidik di Surabaya terhadap Pemanfaatan Rumah Belajar dalam Pembelajaran, Surabaya: makalah Duta Rumah Belajar Tahun 2017 tidak diterbitkan.

Pustekkom. (2013). Kelas Maya: Panduan Pengguna Sistem Guru. Jakarta: Pusat Teknologi Informasi dan Komunikasi Pendidikan.

Warsita, B. (2017). Pemanfaatan Rumah Belajar dalam Kegiatan Pembelajaran, Jakarta: Pustekkom Kemdikbud, Bahan Presentasi dalam Kegiatan Bimtek Pemanfaatan Rumah Belajar 2017 tidak diterbitkan.

Warsita, B. (2017). Pengembangan Bahan Belajar Berbasis Multimedia Untuk

Pembelajaran Abad 21, Jakarta: Makalah di sajikan Pada Kegiatan Lokakarya Pengembangan Bahan Ajar Berbasis Multimedia di Puskurbuk Balitbang Kemdikbud, tangal 20-21 April 2017 tidak diterbitkan. 